\title{
Prepartum application of internal teat sealant or intramammary amoxicillin on dairy heifers: Effect on udder health, survival, and performance
}

\author{
V. S. Machado and R. C. Bicalho ${ }^{1}$ \\ Department of Population Medicine and Diagnostic Sciences, College of Veterinary Medicine, Cornell University, Ithaca, NY 14853
}

\begin{abstract}
Intramammary infusion of antimicrobials (IA) and application of an internal teat sealant (ITS) at the end of the lactation is a common strategy to prevent and treat intramammary infections during the dry period. In heifers, precalving IA has been reported to improve udder health and milk quality; however, the effect of ITS in heifers housed in freestall barns is still unknown. The objective of this study was to investigate the effect of prepartum application of ITS or IA on udder health of dairy heifers. A total of 886 heifers were randomly allocated into 1 of 4 treatment groups when they were $245 \pm 3 \mathrm{~d}$ pregnant. Control heifers $(\mathrm{CON})$ did not receive any treatment. Heifers in the ITS group received the application of ITS containing $2.6 \mathrm{~g}$ of bismuth subnitrate. Animals in the IA group received intramammary administration of $62.5 \mathrm{mg}$ of amoxicillin. Heifers in IA+ITS group received intramammary administration of amoxicillin followed by ITS application. The follow-up period was $270 \mathrm{~d}$ in milk (DIM). Clinical mastitis was diagnosed and treated by trained farm personnel throughout the study period. Composite milk somatic cell counts (SCC) were determined monthly for the first 9 mo of lactation by Dairy Herd Improvement Association. Subclinical mastitis was defined as a cow having a SCC $>200,000$ cells $/ \mathrm{mL}$ for at least 1 test day and not diagnosed with clinical mastitis during the study period. At $7 \pm 3$ DIM, composite milk samples were collected for bacteriological analysis for a subset of the study animals. The presence of pathogens in milk at $7 \pm 3$ DIM was more frequently detected in the CON heifers compared with animals enrolled in the treatment groups. Heifers in IA+ITS group had a decreased incidence of clinical mastitis compared with CON heifers (12.9 vs. $21.4 \%$ ). Additionally, the incidence of subclinical mastitis was decreased for IA+ITS heifers compared with CON counterparts
\end{abstract}

Received June 29, 2017.

Accepted October 18, 2017

${ }^{1}$ Corresponding author: rcb28@cornell.edu
(20.1 vs. $43.8 \%$ ). During the first 9 mo of lactation, IA and IA+ITS heifers had lower SCC linear scores compared with ITS and CON counterparts. Although IA+ITS treatment successfully improved udder health, it did not result in better milk yield, fertility, and survivability. In conclusion, ITS alone was not effective in improving udder health; however, the combination of ITS and IA decreased the incidence of clinical and subclinical mastitis during the first 9 mo of lactation. Additionally, IA+ITS had a long-term effect on the SCC linear score throughout the study period.

Key words: heifer mastitis, teat sealant, antibiotic

\section{INTRODUCTION}

Mastitis is often described as the most important disease for the modern dairy industry due to reduced milk production, discarded milk, treatment cost, antibiotic usage, impaired fertility, and premature culling. Clinical mastitis is also a welfare issue, as it is often associated with severe systemic signs of illness, leading to pain and discomfort (Halasa et al., 2007). Somatic cells are mostly cells of the immune system and reflect the inflammatory response to IMI (Schukken et al., 2003). Somatic cell count, or a parameter derived from this count (e.g., linear scores, used by DHIA), is largely used to monitor the level of IMI and milk quality in individual cows (Schukken et al., 2003). Thresholds of 200,000 and 250,000 cells/mL have been systematically used to define subclinical mastitis (Laevens et al., 1997; Schepers et al., 1997). Bulk milk SCC is used as an overall barometer for herd-level milk quality (Norman et al., 2000). In fact, the legal maximum bulk tank SCC for milk shipments is $750,000 \mathrm{cell} / \mathrm{mL}$ in the United States and 400,000 cell $/ \mathrm{mL}$ in the European Union, Canada, Australia, and New Zealand. A primary motive for dairy producers to reduce SCC is because high SCC is associated with reduced milk yield (Hand et al., 2012; Boland et al., 2013). Additionally, marketing agencies pay premiums for milk with low SCC because it reflects in increased milk quality and increased cheese yield (Klei et al., 1998; Mazal et al., 2007). Therefore, improving udder health by decreasing the incidence of 
clinical mastitis and SCC has great economic importance for a dairy enterprise.

Clinical and subclinical mastitis in heifers (primiparous cows) represent a significant challenge to dairy farmers. Heifer mastitis is a multifactorial disease; host, pathogen, and environmental risk factors contribute to the occurrence of the disease (Fox, 2009; McDougall et al., 2009). The incidence of mastitis is higher in heifers than in multiparous cows, especially in early lactation (Barkema et al., 1998). Clinical mastitis caused by environmental pathogens has been reported to be more prevalent in heifers than in older cows, with Streptococcus uberis being the most prevalent pathogen (McDougall et al., 2007; Fox, 2009). For multiparous cows, more than half of early lactation clinical mastitis cases caused by environmental pathogens originated from IMI acquired during the dry period (Green et al., 2002). Similar to multiparous cows, heifers are also susceptible to IMI in the last month of gestation (Parker et al., 2007), as their teat canal openings widen as the time of calving approaches (Kromker and Friedrich, 2009). In a systematic review, it was reported that the majority of studies found CNS to be the most prevalent pathogen found in prepartum IMI in heifers (Fox, 2009). This organism has been reported to be detrimental (Taponen et al., 2007), indifferent (Schukken et al., 2009), or protective (De Vliegher et al., 2003) to mammary gland health. Environmental pathogens are also important to prepartum IMI in heifers (Fox, 2009; McDougall et al., 2009), leading to compromised udder health during the subsequent lactation (Compton et al., 2007a,b).

Dry cow therapy is a strategy that has been adopted in the dairy industry for several decades; it consists in the intramammary infusion of long-acting antimicrobials at the end of the lactation, aiming to prevent and treat IMI during the dry period (Bramley and Dodd, 1984; Green et al., 2002). In heifers, precalving intramammary antibiotic infusion with long-acting antibiotic formulations have been evaluated (Trinidad et al., 1990; Owens et al., 1994; Sampimon et al., 2009). Those formulations have a long milk withholding period, and should not be administered within $45 \mathrm{~d}$ before calving to prevent antibiotic residue at early lactation (Owens et al., 2001). Short-acting formulations of intramammary therapy have also been evaluated in heifers (Oliver et al., 2003; Middleton et al., 2005; Borm et al., 2006), with minimal risk of antibiotic residue if administered $14 \mathrm{~d}$ before expected calving (Oliver et al., 1997). Some studies have shown that such therapies can improve udder health and milk quality, increasing milk production and being economically beneficial (Oliver et al., 2003; Sampimon et al., 2009); however, these benefits are not always observed (Middleton et al., 2005; Borm et al.,
2006). To apply intramammary therapy in prepartum heifers, it is recommended to restrain the animals in trimming chutes, where the farm employees can safely apply the therapy; however, this can be time consuming. Workers can safely apply parenteral therapy with animals retrained by a regular chute or headlocks in a faster manner. Additionally, intramammary infusion of antibiotics can bring bacteria from the teat canal to the mammary gland, increasing the risk of the establishment of a new IMI. Therefore, from a practical perspective, systemic administration of antibiotics would be preferred than intramammary therapy. One study found that intramuscular injections of $5 \mathrm{~g}$ of tylosin for 3 consecutive days did not improve the IMI cure rate (Parker et al., 2008). Additionally, heifers systemically treated with penethamate hydriodide for $2 \mathrm{wk}$ before expected calving date had fewer IMI in early lactation, but it did not improve clinical mastitis incidence (Passchyn et al., 2013).

An internal teat sealant (ITS) containing $2.6 \mathrm{~g}$ of bismuth subnitrate was developed in New Zealand as a nonantimicrobial alternative approach to prevent new IMI during the dry period (Woolford et al., 1998). It was found to be effective to improve udder health during the subsequent lactation in New Zealand (Woolford et al., 1998), the United Kingdom (Huxley et al., 2002), and the United States (Godden et al., 2003). Because ITS therapy does not treat existing IMI, it has been used alone for cows with low SCC or in combination with intramammary antibiotic infusion (IA). It has been reported that ITS has an additive protective effect against new IMI in cows treated with dry cow intramammary antibiotic (Godden et al., 2003; Berry and Hillerton, 2007; Runciman et al., 2010). Internal teat sealant has been adopted as part of dry cow therapy programs by $33.9 \%$ of dairy herds in the United States (USDA-NAHMS, 2014). Several studies from New Zealand have suggested that ITS can also be a useful method for mastitis control for heifers entering the lactating herd. It was reported that the incidence of clinical mastitis associated with bacteria and the prevalence of postpartum IMI was reduced after precalving infusion of ITS (Parker et al., 2007, 2008; Laven and Lawrence, 2008; Compton et al., 2014). It was suggested that the ITS acted as a physical barrier, reducing the invasion of bacteria. However, it is important to highlight that these studies were conducted in New Zealand, where the study heifers were living on pasture, and their milk production was lower compared with well-managed heifers housed in freestall barns. Heifers that produced more milk were more likely to have clinical mastitis (Waage et al., 1998). As the risk factors for IMI are different for heifers in pasture versus freestall barns 
(McDougall et al., 2009), it is unclear that the results found with the application of ITS in different housing systems would be similar.

Therefore, the primary objective of our study was to investigate the effect of prepartum application of ITS or intramammary antibiotic on postpartum udder health of heifers housed in freestall barns. Intramammary infections have been associated with milk and reproductive losses (Tyler et al., 1989; Bijker et al., 2015). In addition to ITS or intramammary antibiotic application potentially affecting udder health, our secondary objective was to evaluate the effect of prepartum application of ITS or intramammary antibiotic on milk yield, fertility, and survivability.

\section{MATERIALS AND METHODS}

\section{Farm and Management}

In this study, 886 pregnant Holstein heifers were enrolled from October 20, 2015, to June 10, 2016, and the follow-up period included the first 9 mo of lactation. The study was conducted on a commercial dairy farm located near Ithaca, New York. The farm milked 3,900 Holstein cows 3 times daily in a 100-stall rotary milking parlor. The animals were housed in freestall barns, with concrete stalls covered with mattresses and bedded with manure solids. All lactating cows were offered a TMR consisting of approximately 55\% forage (corn silage, haylage, and wheat straw) and $45 \%$ concentrate (corn meal, soybean meal, canola, cottonseed, and citrus pulp) on a DM basis. The diet was formulated to meet or exceed the NRC (2001) nutrient requirements for lactating Holstein cows weighing $650 \mathrm{~kg}$ and producing $45 \mathrm{~kg}$ of $3.5 \%$ FCM.

At approximately $350 \mathrm{~d}$ of age, heifers were moved to breeding pens. During the first $30 \mathrm{~d}$ in the breeding pens, heifers were bred solely via AI after visual estrus detection. Heifers that were not inseminated during this $30-\mathrm{d}$ period received prostaglandin injections every 2 wk until they were bred via AI after estrus detection. The reproductive management for lactating cows used a combination of Presynch (Moreira et al., 2001), Ovsynch (Pursley et al., 1995), Resynch (Fricke et al., 2003), and detection of estrus, with a voluntary waiting period of 50 DIM. Thirty percent of lactating cows were bred via timed AI and the remainders were bred via AI after detection of estrus solely by activity monitors (ALPRO; DeLaval, Kansas City, MO).

At 3 mo of age, animals were vaccinated with infectious bovine rhinotracheitis, bovine viral diarrhea types I and II, parainfluenza-3, and bovine respiratory syncytial virus (Vista 5 SQ, Merck Animal Health, NJ), Clostridium chauvoei, Clostridium septicum, Clostridium haemolyticum, Clostridium novyi, Clostridium tetani, and Clostridium perfringens (Covexin 8, Merck Animal Health, Kenilworth, NJ), and received a booster 2 wk later. They received another dose of Vista 5 SQ at 11 mo of age. At $200 \mathrm{~d}$ of gestation, they were immunized for infectious bovine rhinotracheitis, bovine viral diarrhea types I and II, parainfluenza-3, bovine respiratory syncytial virus, Leptospira Pomona, Leptospira Hardjo, Leptospira Grippotyphosa, Leptospira Canicola, and Leptospira Icterohaemorrhagiae (Triangle 9, Boehringer Ingelheim Vetmedica, Inc., St. Joseph, MO), and Covexin 8. At 246 and $260 \mathrm{~d}$ of gestation, they were vaccinated with Escherichia coli (J-Vac, Merial, GA) and Bovine Rota-Coronavius Vaccine, C. perfringens Type C, and E. coli (Scourguard, Zoetis, Florham Park, NJ). During the lactation, they were vaccinated with Vista $5 \mathrm{SQ}$ and J-Vac at $35 \mathrm{DIM}$, and at the first pregnancy diagnosis date they received another dose of J-Vac.

\section{Study Design, Inclusion Criteria, and Treatment Groups}

The study unit was the heifer, as all 4 glands within a heifer received the same treatment. Prior to commencement of the study, statistical power and sample size calculations were performed. Sample size was calculated assuming that intramammary infusion of a teat sealant or amoxicillin would decrease the SCC linear score in the first DHIA test-day by 0.4 units, considering a significance level of $\alpha=0.05$, a power of $80 \%$, and a standard deviation of 1.5 units of SCC linear score. According to this calculation, 222 heifers were needed in each treatment group. We used SCC linear score in the first DHIA test because SCC in early lactation have been associated with SCC during the entire lactation (De Vliegher et al., 2004). To account for eventual data loss, we intended to enroll 250 heifers in each treatment group. However, due to our clinical duties and changes in farm routine, enrollment was ceased before reaching 250 animals per treatment group. To verify if more animals should be enrolled, we performed a preliminary analysis of the data after the last day of enrollment. The first month SCC linear scores of a total of 709 animals were available for analysis. Data was analyzed using the ANOVA function in JMP 12 (SAS Institute Inc., Cary, NC). The SCC linear score was 3.26, 3.00, 2.60, and 2.52 for cows enrolled in CON, ITS, IA, and IA+ITS. In this analysis, after adjusting for multi comparison, statistical differences were detected between CON versus IA $(P<0.01)$ and CON versus IA + ITS $(P$ $<0.01)$. The decision of ceasing enrollment was taken after this preliminary analysis was performed.

Late pregnant heifers were enrolled on a weekly basis. Farm personnel selected heifers for routine hoof trim- 
ming based on stage of gestation (approximately $30 \mathrm{~d}$ before calving) and stocking density of prefresh pens. All heifers selected for hoof trimming were eligible to be enrolled in the study. A total randomized field trial study design was used. Heifers were randomly allocated into 1 of 4 treatment groups using the random number function of Excel (Microsoft Corp., Redmond, MA). Treatment ITS consisted of application of an internal teat sealant containing $2.6 \mathrm{~g}$ of bismuth subnitrate (Orbeseal, Zoetis Animal Health). Treatment IA consisted of intramammary administration of $62.5 \mathrm{mg}$ of amoxicillin (Amoxi-Mast, Merck Animal Health). Treatment IA+ITS consisted of a combination of intramammary administration of $62.5 \mathrm{mg}$ of amoxicillin followed by application of an internal teat sealant containing $2.6 \mathrm{~g}$ of bismuth subnitrate. Treatment CON served as the control group, and heifers enrolled in this group did not receive any treatment.

Enrollment and treatment application was performed by the authors while animals were restrained for hoof trimming with a standing hoof trimming chute. After the animals were restrained, their udders were visually inspected by the investigators. Heifers with visual signs of mastitis (swollen quarters) were not included in the study. Before application of treatments, the teats were cleaned and sanitized to avoid forcing bacteria present on the teat end into the mammary gland and causing infection. Cleaning and sanitization methods followed standard recommendations by the National Mastitis Council (NMC, 1999). Teats were first cleaned and dried, and then dipped with iodine solution (Iodozyme; DeLaval). After $30 \mathrm{~s}$, teats were wiped with individual disposable towel and subsequently disinfected with gauze soaked with $70 \%$ alcohol. The teat orifice was disinfected using cotton swab soaked in $70 \%$ alcohol. After application of treatment, teats were dipped in iodine solution. Teat cleaning and sanitization was not performed for heifers enrolled in the CON group. Animals that calved within $10 \mathrm{~d}$ after enrollment had their milk discarded until $10 \mathrm{~d}$ after enrollment. Enrollment was followed by $28 \mathrm{~d}$ of meat withholding. During the entire study period, testing for antimicrobial residue was performed before every milk shipment using SNAPduo Beta-Tetra Test ST (Idexx Laboratories, Inc., Westbrook, ME).

\section{Milk Sample Collection and Analysis}

Composite milk samples were collected for a subset of the study animals $(\mathrm{n}=509)$ at $7 \pm 3$ DIM. Samples were collected based on the availability of the authors to be at the farm during morning milking. Immediately after the morning milking and before application of postdipping solution, teats were scrubbed with gauze soaked with iodine solution and then with gauze soaked in $70 \%$ alcohol. The first streams of milk of each quarter were discarded. An aliquot of approximately $10 \mathrm{~mL}$ of composite milk sample was collected in a sterile $50 \mathrm{~mL}$ tube (VWR International, Radnor, PA). Samples were kept on ice until they were frozen at $-20^{\circ} \mathrm{C}$. Samples were submitted to the Quality Milk Production Services laboratory at Cornell University for bacterial identification using standard aerobic culture. Using a sterile cotton swab, milk samples were plated onto trypticase soy agar plates supplemented with $5 \%$ of sheep blood and $0.1 \%$ esculin (bioMerieux, Durham, NC). Bacterial growth was identified after 24 and 48 $\mathrm{h}$ of incubation according to National Mastitis Council standards (NMC, 1999). Cultures were evaluated for size, color, hemolytic pattern, and odor. Additional tests for further bacterial classification included Gram stain, biochemical tests, and wet mount microscopic evaluations. Staphylococcus aureus and Staphylococcus spp. were identified by tube coagulate test and hemolytic pattern. Presence or absence of esculin hydrolysis, Lancefield group C typing (PathoDx strep grouping latex agglutination test, Remel, San Diego, CA), and growth or growth inhibition on Bile Esculin Azide Agar (Enterococcosel, Becton, Dickinson and Co., Franklin Lakes, NJ) were used to differentiate Streptococcus dysgalactiae, Streptococcus uberis, and Streptococcus spp. Morphologic characteristics of colonies on MacConkey agar, production of indole, motility, and utilization of citrate were evaluated to identify E. coli and Klebsiella spp. Colony characteristics, presence of complete hemolysis, and Gram stain were used to identify Trueperella pyogenes. No mycoplasma culture or anaerobic culture was performed on the samples (Oikonomou et al., 2012).

\section{Case Definition}

Clinical mastitis was diagnosed and treated by trained farm personnel who follow a specific diagnostic protocol designed by the staff of the Ambulatory and Production Medicine Clinic, Cornell University. Cows were monitored for clinical mastitis at every milking by stripping and visual inspection of the udder. Clinical mastitis was defined by the presence of abnormal changes in the udder or milk. Trained farm personnel aseptically sampled milk from affected quarters and used an on-farm culture system (Accumast, FERA Animal Health LCC, Ithaca, NY) to identify specific mastitis pathogens. Antimicrobial treatment of clinical mastitis cases was based on milk culture outcomes. Cows with milk culture-positive for Streptococcus spp. were treated with intramammary infusion of ceftiofur 
(Spectramast LC, Zoetis) according to the product label. Mastitis cases that were negative for Streptococcus spp. were not treated with intramammary antibiotics.

Composite milk SCC were determined monthly by DHIA, and the SCC linear score was automatically calculated and inputted into the farm's DairyComp 305 database (Valley Agricultural Software, Tulare, CA). Subclinical mastitis was defined as a cow having a SCC $>200,000$ cells $/ \mathrm{mL}$ for at least 1 of the 9 DHIA test days and not diagnosed with clinical mastitis during the study period. Data regarding survivability, reproduction, milk yield, and SCC during the lactation was extracted from the farm's DairyComp 305 database. Body condition scores were determined for all heifers at enrollment, using a 5-point scale with a quarter-point system as previously described (Edmonson et al., 1989).

\section{Statistical Analyses}

Descriptive statistical analyses were undertaken in SAS version 9.4 using the FREQ and MEANS procedures (SAS Institute Inc.). The effect of treatment on the outcome of bacteriology analysis of composite milk samples collected at $7 \pm 3 \mathrm{DIM}$ and at clinical mastitis diagnosis was evaluated using the Chi-squared test in JMP 12. To evaluate the effect of treatment on the incidence of clinical mastitis, clinical mastitis that required antibiotic therapy, and subclinical mastitis during the first $9 \mathrm{mo}$ of lactation, 3 logistic models were fitted in SAS using the GLIMMIX procedure. The Dunnett's test was used to account for multiple comparisons between treatment groups ( $\mathrm{CON}$ was the reference group).

Four general linear models were fitted to the data using the MIXED procedure of SAS. The dependent variables evaluated were average daily milk production $(\mathrm{kg} / \mathrm{d})$, average daily FCM production $(\mathrm{kg} / \mathrm{d})$, average daily ECM production $(\mathrm{kg} / \mathrm{d})$, and SCC linear score. The data comprised a series of repeated measures of each dependent variable throughout the 9 DHIA tests. To account appropriately for within-cow correlation, the error term was modeled by imposing a first-order autoregressive covariance structure for all 4 models. Visual evaluation of the distribution plot of the Studentized residuals was used to confirm that the residuals were normally distributed.

To assess the effect of treatment on likelihood of clinical mastitis during the first 9 mo of lactation, conceiving, and likelihood of being culled or dead, 3 multivariable Cox's proportional hazard models were fitted using the PHREG procedure in SAS. To evaluate the likelihood of clinical mastitis, cows were right-censored if not diagnosed with clinical mastitis before culling, death, or the end of the data collection period. For analysis of reproduction, cows were right-censored if not diagnosed as being pregnant before culling, death, or the end of the data collection period. For analysis of survival, cows were right-censored if they were alive at the end of the data collection period. To illustrate the effects of treatment on time to clinical mastitis diagnosis, median calving-to-conception interval, and the median time to culling or death, Kaplan- Meier survival analysis was performed using Medcalc version 17.2 (MedCalc Software, Mariakerke, Belgium); the Logrank test was used to compute $P$-values.

For all multivariate models described above, independent variables and their respective interactions were kept when $P<0.10$. The variable treatment was forced into all statistical models even in the absence of statistical significance. Age in days at enrollment, BCS at enrollment, and days of gestation at enrollment were offered to all models.

\section{RESULTS}

\section{Descriptive Statistics}

Descriptive statistics regarding average age at enrollment (days), average BCS at enrollment, average gestation length at enrollment, average days between enrollment and parturition, total number of animals enrolled, and number of excluded animals are presented in Table 1. Animals were excluded from study because they were sold or culled before parturition. These heifers were culled because they were found to not be pregnant when veterinarians were checking overdue cows. A total of 9 heifers calved within $10 \mathrm{~d}$ after enrollment $(\mathrm{CON}=$ 2 , ITS $=1, \mathrm{IA}=3, \mathrm{IA}+\mathrm{ITS}=3)$. After calving, those animals were moved to a waste milk pen, where they stayed until the end of milk-withholding period.

\section{Milk Samples Bacteriology}

Composite milk samples were collected at $7 \pm 3$ DIM from a subset $(\mathrm{n}=509,57 \%)$ of the heifers enrolled in the study. The aerobic culture results from those samples are presented in Table 2. From the 509 samples collected, 131 samples $(26 \%)$ were characterized as contaminated. The proportion of contaminated samples were not different between treatment groups $(P=0.39)$, and those samples were not included in the analysis comparing the culture outcomes between treatment groups. Therefore, samples from 378 animals were included in the final analysis ( $74 \%$ of sampled heifers and $43 \%$ of enrolled heifers).

Pathogens were not detected in $94 \%$ of the remaining 378 milk samples, with CON having the lowest proportion of no growth samples compared with the other 
Table 1. Descriptive statistics of treatment groups

\begin{tabular}{|c|c|c|c|c|c|}
\hline Item & $\mathrm{CON}^{1}$ & ITS $^{2}$ & $\mathrm{IA}^{3}$ & $\mathrm{IA}+\mathrm{ITS}^{4}$ & $P$-value \\
\hline Average BCS at enrollment $( \pm \mathrm{SE})$ & $3.64(0.01)$ & $3.63(0.01)$ & $3.61(0.01)$ & $3.62(0.01)$ & 0.52 \\
\hline Average days of gestation at enrollment $( \pm \mathrm{SE})$ & $245.8(0.46)$ & $245.5(0.46)$ & $245.9(0.46)$ & $246.0(0.46)$ & 0.86 \\
\hline Total enrolled animals (\%) & $222(25.1)$ & $221(24.9)$ & $221(24.9)$ & $222(25.1)$ & \\
\hline Total excluded animals (\%) & $2(0.9)$ & $3(1.4)$ & $0(0)$ & $2(0.9)$ & 0.22 \\
\hline
\end{tabular}

${ }^{1} \mathrm{CON}=$ control, no intervention.

${ }^{2}$ ITS $=$ internal teat sealant (2.6 g of bismuth subnitrate).

${ }^{3} \mathrm{IA}=$ intramammary antibiotic $(62.5 \mathrm{mg}$ of amoxicillin).

${ }^{4} \mathrm{IA}+\mathrm{ITS}=$ intramammary antibiotic $(62.5 \mathrm{mg}$ of amoxicillin) followed by internal teat sealant $(2.6 \mathrm{~g}$ of bismuth subnitrate).

treatment groups. Staphylococcus spp. were the most prevalent pathogens detected in milk samples collected at $7 \pm 3$ DIM, and were detected more frequently in samples collected from CON heifers compared with the other treatment groups. The other pathogens detected in the samples were Strep. dysgalactiae, Strep. uberis, and Staph. aureus, but in very small frequencies.

\section{Clinical Mastitis}

The effect of treatments on clinical mastitis incidence during the first 9 mo of lactation is presented in Table 3. The IA+ITS treatment decreased the incidence of clinical mastitis when compared with CON (12.9 vs. $21.4 \%, P=0.05)$; however, ITS or IA applied separately did not decrease the incidence of clinical mastitis. The clinical mastitis incidences for ITS and IA were 21.6 and $21.2 \%$, respectively. Additionally, survival analysis was fitted to the data to evaluate the likelihood of clinical mastitis during the first 9 mo of lactation (Figure 1). Heifers enrolled in the CON group were 1.74 times more likely to have clinical mastitis compared with IA+ITS cows $(P=0.02)$. Median time to clinical mastitis was not estimated because more than $50 \%$ of cows in all treatment groups did not have the disease within 9 mo of lactation. However, for heifers that received
ITS or IA treatments, the likelihood of clinical mastitis was not different compared with CON counterparts $[\mathrm{HR}=1.03(P=0.87)$ and $\mathrm{HR}=0.99(P=0.96)$, respectively].

The description of quarters affected and milk culture outcomes in the first clinical mastitis event is presented in Table 4. Overall, $53.2 \%$ of clinical mastitis milk cultures resulted in no pathogen growth. The most prevalent pathogen found in mastitis cases was Streptococcus spp., followed by E. coli, Klebsiella oxytoca, and CNS. At the farm where the study was conducted, the employees followed a clinical mastitis selective treatment protocol. Clinical mastitis cases were only treated with an intramammary infusion of antibiotics if Streptococcus spp. was detected in the milk culture. Although IA+ITS decreased the incidence of clinical mastitis compared with CON, the incidence of clinical mastitis cases that were treated with antibiotics was not affected by treatment (Table $3, P=0.17$ ).

\section{Subclinical Mastitis and SCC Linear Score}

Only cows that were not diagnosed with clinical mastitis during the study period were included in the subclinical mastitis analysis. For those cows, subclinical mastitis was defined as a cow having a SCC >200,000

Table 2. Outcome of bacteriology analysis of composite milk samples collected at $7 \pm 3 \mathrm{DIM}^{1}$

\begin{tabular}{|c|c|c|c|c|c|c|c|c|c|}
\hline Culture & \multicolumn{2}{|c|}{$\mathrm{CON}$} & \multicolumn{2}{|c|}{ ITS } & \multicolumn{2}{|c|}{ IA } & \multicolumn{2}{|c|}{$\mathrm{IA}+\mathrm{ITS}$} & $P$-value \\
\hline Negative & 73 & 82.9 & 104 & 100.0 & 80 & 90.9 & 97 & 98.9 & $<0.01$ \\
\hline CNS & 12 & 13.6 & 0 & 0 & 3 & 3.4 & 1 & 1.0 & \\
\hline Streptococcus dysgalactiae & 2 & 2.3 & 0 & 0 & 2 & 2.3 & 0 & 0 & \\
\hline Streptococcus uberis & 0 & 0 & 0 & 0 & 2 & 2.3 & 0 & 0 & \\
\hline
\end{tabular}




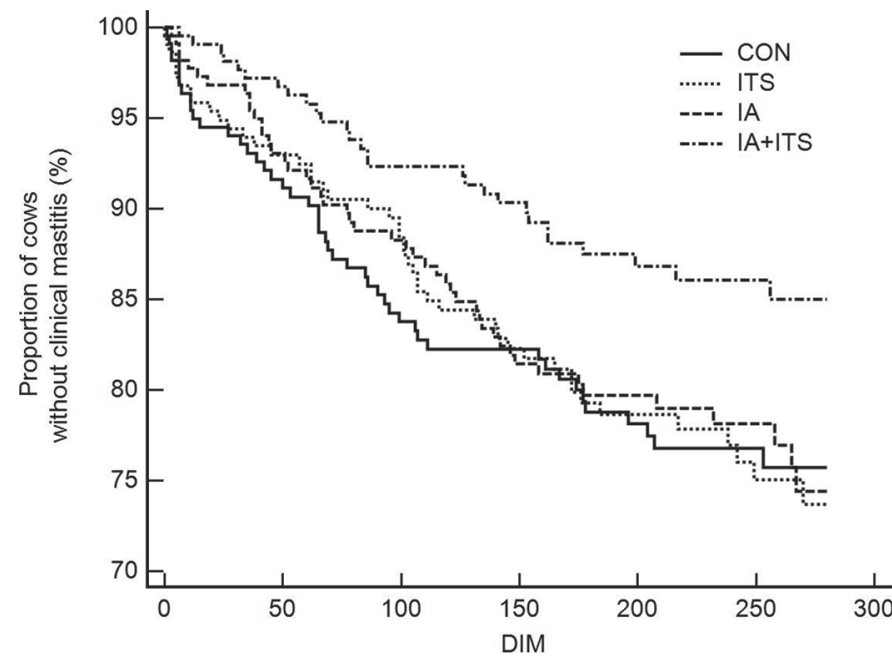

Figure 1. Kaplan-Meier survival analysis of probability of clinical mastitis for control cows (CON) and cows that received an internal teat sealant (ITS; $2.6 \mathrm{~g}$ of bismuth subnitrate), intramammary application of antibiotic (IA; $62.5 \mathrm{mg}$ of amoxicillin), or the combination of antibiotic and internal teat sealant (IA+ITS). Median time to clinical mastitis was not estimated because more than $50 \%$ of the cows in all treatment groups did not have clinical mastitis within 9 mo of lactation. Cows that received IA+ITS were less likely to have clinical mastitis compared with cows enrolled in the other treatment groups $(P=0.04)$.

cells $/ \mathrm{mL}$ for at least 1 test day during the first $9 \mathrm{mo}$ of lactation. The effect of treatments on subclinical mastitis likelihood and incidence is presented in Table 3. The incidence of subclinical mastitis in the first 9 mo of lactation was $43.8,40.8,33.2$, and $20.1 \%$ for treatment groups CON, ITS, IA, and IA+ITS, respectively. The IA+ITS treatment decreased the odds of a cow developing subclinical mastitis compared with CON treatment (odds ratio $=0.34, P<0.01$ ). The incidence of subclinical mastitis was not affected by IA or ITS treatments $(P=0.92$ and 0.12 , respectively).
The effect of treatment of SCC linear scores during the study period is presented in Table 5, and linear scores by treatment and month of lactation is illustrated in Figure 2. Compared with $\mathrm{CON}$, the treatments IA+ITS and IA decreased the SCC linear score throughout the first 9 mo of lactation $(P<0.01)$. A numerical reduction was observed for treatment ITS in comparison to CON; however, it was not statistically different $(P=0.15)$.

\section{Milk Production, Survivability, and Reproductive Performance}

Treatment did not have any effect on average daily milk yield, average daily FCM production, and average daily ECM production (Table 5). The effect of treatment on milk yield, FCM yield, and ECM yield by month of lactation is illustrated in Figure 3. Additionally, treatment did not improve reproductive performance (Table 6). The median calving-to-conception interval (with 95\% CI) for CON, ITS, IA, and IA+ITS cows was 107 (100-122), 110 (99-123), 109 (102-130) and 103 (99-109), respectively $(P=0.55$, Figure 4A). Furthermore, treatment had no effect on survivability. The hazard ratio for culling or death is presented in Table 6. Median time until culling or death was not estimated because more than $50 \%$ of the cows in all treatment groups were still alive by the end of the follow-up period (Figure 4B, $P=0.31$ ).

\section{DISCUSSION}

The main objective of the present study was to evaluate the effect of pre-calving application of ITS or IA on udder health of dairy heifers housed in freestall barns. Studies with similar goals have been published previously. The effect of precalving application of ITS

Table 3. Effect of treatment on the incidence of clinical mastitis, mastitis treated with intramammary antibiotics, and subclinical mastitis during the first 9 mo of lactation ${ }^{1}$

\begin{tabular}{|c|c|c|c|c|c|c|}
\hline Item & Measurement & $\mathrm{CON}$ & ITS & IA & $\mathrm{IA}+\mathrm{ITS}$ & $\begin{array}{l}\text { Overall } \\
P \text {-value }\end{array}$ \\
\hline Clinical mastitis & $\begin{array}{l}\text { Adjusted incidence }(\%) \\
\text { Adjusted odds ratio } \\
(95 \% \mathrm{CI}) \\
\text { Individual } P \text {-value }\end{array}$ & $\begin{array}{c}21.4 \\
\text { Baseline }\end{array}$ & $\begin{array}{l}21.6 \\
1.01 \\
(0.58-1.75) \\
1.00\end{array}$ & $\begin{array}{l}21.2 \\
0.99 \\
(0.57-1.72) \\
1.00\end{array}$ & $\begin{array}{l}12.9 \\
0.54 \\
(0.29-1.00) \\
0.05\end{array}$ & 0.06 \\
\hline Treated clinical mastitis & $\begin{array}{l}\text { Adjusted incidence }(\%) \\
\text { Adjusted odds ratio } \\
(95 \% \mathrm{CI}) \\
\text { Individual } P \text {-value }\end{array}$ & $\begin{array}{c}5.1 \\
\text { Baseline }\end{array}$ & $\begin{array}{l}2.9 \\
0.56 \\
(0.18-1.76) \\
0.49\end{array}$ & $\begin{array}{l}7.8 \\
1.55 \\
(0.62-3.92) \\
0.54\end{array}$ & $\begin{array}{l}5.8 \\
1.15 \\
(0.43-3.05) \\
0.97\end{array}$ & 0.17 \\
\hline Subclinical mastitis & $\begin{array}{l}\text { Adjusted incidence (\%) } \\
\text { Adjusted odds ratio } \\
(95 \% \mathrm{CI}) \\
\text { Individual } P \text {-value }\end{array}$ & $\begin{array}{c}43.8 \\
\text { Baseline }\end{array}$ & $\begin{array}{l}40.8 \\
0.88 \\
(0.52-1.49) \\
0.92\end{array}$ & $\begin{array}{l}33.2 \\
0.64 \\
(0.37-1.09) \\
0.12\end{array}$ & $\begin{array}{l}20.1 \\
0.34 \\
(0.19-0.59) \\
<0.01\end{array}$ & $<0.01$ \\
\hline
\end{tabular}

${ }^{1} \mathrm{CON}=$ control, no intervention; ITS = internal teat sealant (2.6 g of bismuth subnitrate); IA = intramammary antibiotic (62.5 mg of amoxicillin); IA+ITS = intramammary antibiotic ( $62.5 \mathrm{mg}$ of amoxicillin) followed by internal teat sealant (2.6 $\mathrm{g}$ of bismuth subnitrate). 
Table 4. Description of clinical mastitis cases; number of affected quarters and mastitis milk sample bacteriology outcomes by treatment group ${ }^{1}$

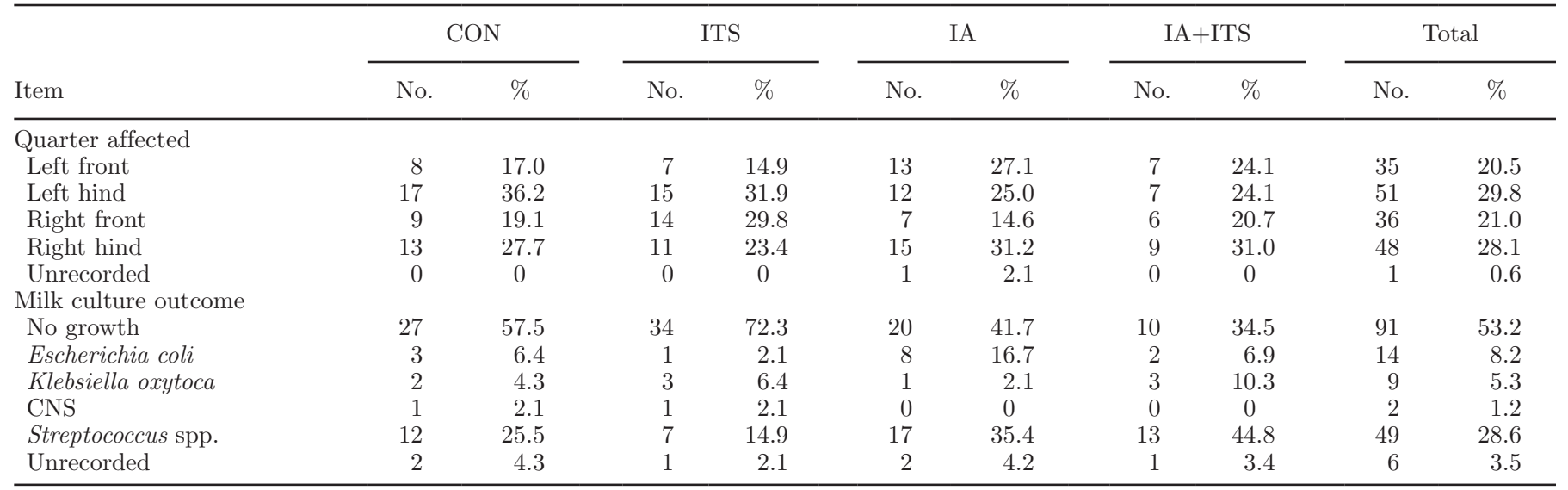

${ }^{1}$ Only the first case of clinical mastitis per cow was included in this analysis. $\mathrm{CON}=$ control, no intervention; ITS $=$ internal teat sealant $(2.6$ $\mathrm{g}$ of bismuth subnitrate); IA = intramammary antibiotic (62.5 $\mathrm{mg}$ of amoxicillin); IA+ITS = intramammary antibiotic (62.5 mg of amoxicillin) followed by internal teat sealant (2.6 $\mathrm{g}$ of bismuth subnitrate).

on udder health have been evaluated for heifers living on pasture (Parker et al., 2007; Laven and Lawrence, 2008; Compton et al., 2014). It was unclear that the results reported in those trials would be meaningful to nonpasture-based systems, as the risk factors for IMI are different for heifers in pasture versus freestall barns (McDougall et al., 2009). Additionally, other studies have investigated how prepartum IA therapy influenced udder health of dairy heifers (Oliver et al., 2004; Middleton et al., 2005; Borm et al., 2006); however, none of those studies evaluated ITS in addition to IA therapy. Therefore, here we report novel findings on the effect of prepartum ITS application on udder health of dairy heifers housed in freestall barns and how mammary gland health was influenced by precalving IA therapy followed by ITS application. Our study was conducted in 1 large dairy, and results presented here should not be blindly generalized to other herds.

Many studies evaluating ITS or IA have reported IMI cure rates. They considered bacteriological findings from intramammary secretion before treatment application and milk samples in the first week postpartum
(Oliver et al., 2004; Parker et al., 2007, 2008). To collect samples before calving, it is necessary to remove the keratin plug that the majority of heifers have during that period. This plug serves as a physical barrier against pathogens, and its removal can represent a potential risk of IMI establishment. However, Parker et al. (2007) reported that mammary gland secretion collection 1 mo before calving did not increase the risk of postpartum IMI or clinical mastitis for pasture-based heifers. Nevertheless, it is intuitive to consider that the environmental pathogen pressure is greater in freestall barns compared with pasture. Therefore, we considered that our study animals were at a higher risk of developing IMI after mammary gland secretion collection. Hence, we opted to skip sample collection before calving and we could not report any results on pre-existing IMI, cure rates, and new IMI. Using the same rationale, we did not use an intramammary placebo for the CON heifers. We considered that this type of intervention could potentially increase the risk of IMI for the CON animals because it would open the teat canal and facilitate the access of bacteria to the mammary gland.

Table 5. Least squares means of SCC linear score, milk yield, 3.5\% FCM yield, and ECM yield, and $P$-values for the main effect of treatment, time, and their interaction on the final repeated measures models ${ }^{1}$

\begin{tabular}{|c|c|c|c|c|c|c|c|}
\hline \multirow[b]{2}{*}{ Item } & \multicolumn{4}{|c|}{ LSM $(95 \%$ CI $)$} & \multicolumn{3}{|c|}{$P$-value } \\
\hline & $\mathrm{CON}$ & ITS & IA & $\mathrm{IA}+\mathrm{ITS}$ & Treament & Month & $\begin{array}{l}\text { Treatment } \\
\times \text { month }\end{array}$ \\
\hline SCC linear score & $2.4(2.2-2.5)$ & $2.2(2.0-2.3)$ & $1.9(1.8-2.0)$ & $1.8(1.7-2.0)$ & $<0.01$ & $<0.01$ & 0.06 \\
\hline Milk (kg/d) & $35.6(34.8-36.5)$ & $35.8(34.9-36.6)$ & $35.9(35.1-36.7)$ & $36.1(35.2-36.9)$ & 0.89 & $<0.01$ & 0.82 \\
\hline FCM (kg/d) & $38.1(37.4-38.8)$ & $38.1(37.4-38.8)$ & $38.3(37.6-39.0)$ & $38.4(37.7-39.1)$ & 0.91 & $<0.01$ & 0.91 \\
\hline ECM $(\mathrm{kg} / \mathrm{d})$ & $38.0(37.3-38.6)$ & $37.8(37.1-38.5)$ & $38.0(37.3-38.7)$ & $38.4(37.7-39.1)$ & 0.66 & $<0.01$ & 0.69 \\
\hline
\end{tabular}

${ }^{1} \mathrm{CON}=$ control, no intervention; ITS = internal teat sealant (2.6 g of bismuth subnitrate); IA = intramammary antibiotic (62.5 mg of amoxicillin); IA+ITS = intramammary antibiotic ( $62.5 \mathrm{mg}$ of amoxicillin) followed by internal teat sealant (2.6 $\mathrm{g}$ of bismuth subnitrate). 


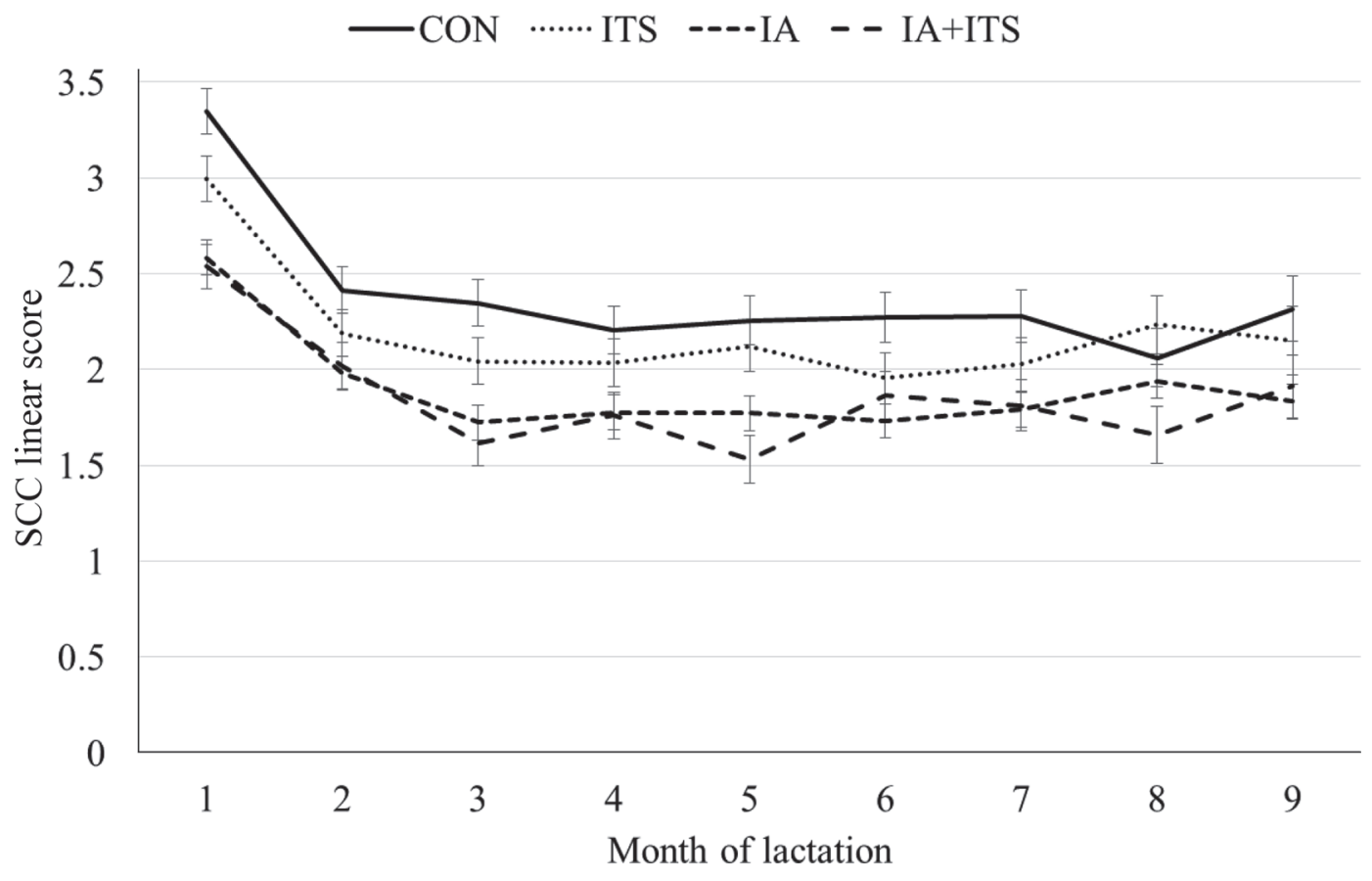

Figure 2. The effect of treatment on SCC linear scores by month of lactation. The average SCC linear scores for control cows (CON) and cows that received an internal teat sealant (ITS; $2.6 \mathrm{~g}$ of bismuth subnitrate), intramammary application of antibiotic (IA; $62.5 \mathrm{mg}$ of amoxicillin), or the combination of antibiotic and internal teat sealant (IA+ITS) are presented in Table 5. The error bars indicate SEM.

Additionally, we did not apply a teat disinfectant dip in the CON animals. Teat disinfectant application during the milking routine is an important tool for mastitis prevention, as they reduce the teat skin pathogen loads and decrease the occurrence of new IMI (Enger et al., 2015). Although it is unlikely that a single application of teat disinfectant could influence the new IMI rate, we acknowledge that not applying a teat dip to $\mathrm{CON}$ cows could have potentially added bias in our observations. However, the interventions to CON group were limited to what was conventionally done for prefresh heifers.

We hypothesized that precalving ITS application would prevent new IMI and IA would treat pre-existing IMI, and that such therapies would improve udder health by decreasing clinical mastitis and SCC in early lactation. Nevertheless, we expected that the best results would be achieved with the combination of ITS and IA, similar to findings reported for multiparous cows (Woolford et al., 1998; Berry and Hillerton, 2007; Runciman et al., 2010). In our study, ITS alone decreased the presence of IMI at $7 \pm 3$ DIM compared with CON, which is in accordance with others that also found that ITS decreased the prevalence of IMI after calving (Parker et al., 2007, 2008; Laven and Lawrence, 2008). Here, ITS did not improve udder health when considering the incidence of clinical and subclinical mastitis and the SCC during the first 9 mo of lactation; however, others have reported that ITS decreased the incidence of clinical mastitis in pasture-based heifers (Parker et al., 2007, 2008). Laven and Lawrence (2008) reported that, for heifers living on pasture, ITS did not affect SCC, which is in accordance with our findings.

In our study, we used an intramammary antibiotic lactating formulation (short-acting) containing $62.5 \mathrm{mg}$ of amoxicillin, which is labeled to treat clinical mastitis in lactating dairy cows. We opted to use a lactating cow antibiotic formulation instead of a nonlactating formulation (long-acting) because of the increased risk of antibiotic residue in milk in the first week of lactation when using the long-acting form (Oliver et al., 1992). Many studies have evaluated precalving intramammary infusion of long-acting antibiotic formulation (Trinidad et al., 1990; Owens et al., 1994; Sampimon et al., 2009) or systemic antibiotic therapy (Parker et al., 2008; Bryan and Taylor, 2009; Passchyn et al., 2013). In those studies, the concentration and duration of antimicrobials in the mammary gland could have been significantly different when compared with the approach we used. Therefore, we believe that it is more appropriate to compare our results with others that have also evaluated the effect of short-acting formulations of intramammary antibiotics. Although we evaluated amoxicillin as our IA therapy, others have evaluated cloxacillin (Oliver et al., 1992), cephapirin (Oliver et al., 1992; Borm et al., 2006), penicillin-no- 


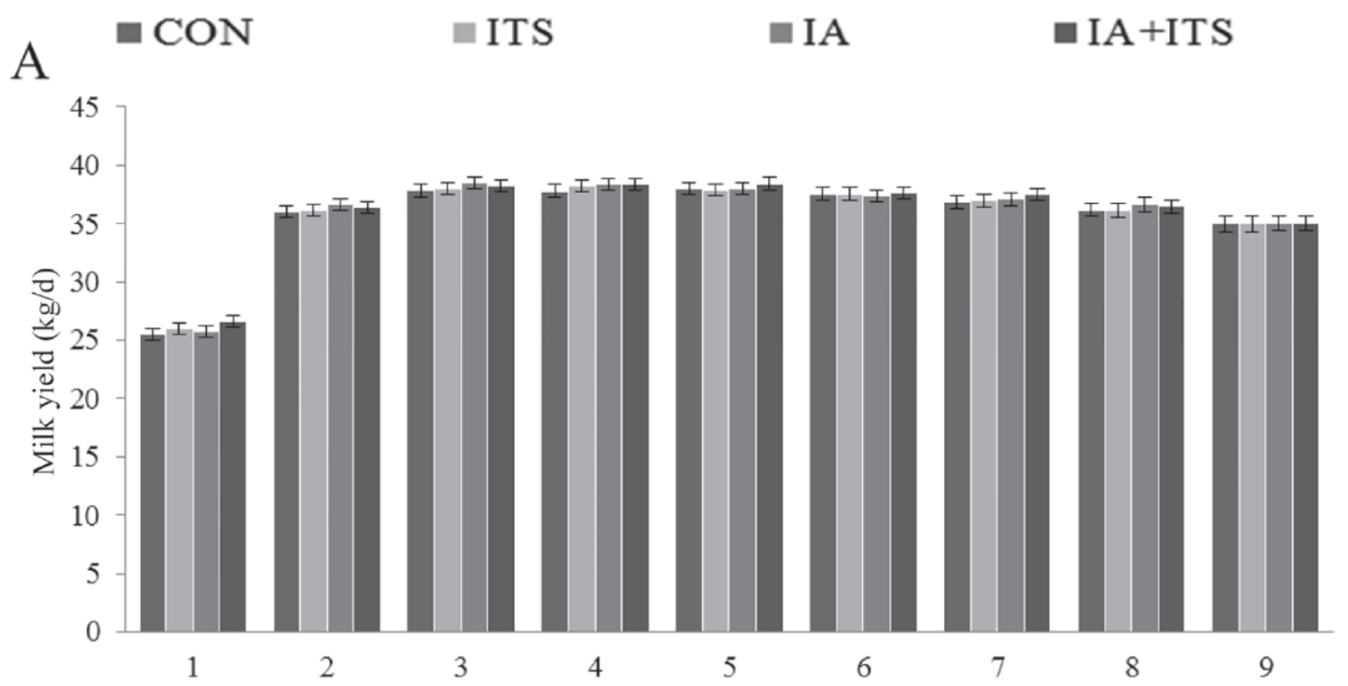

B
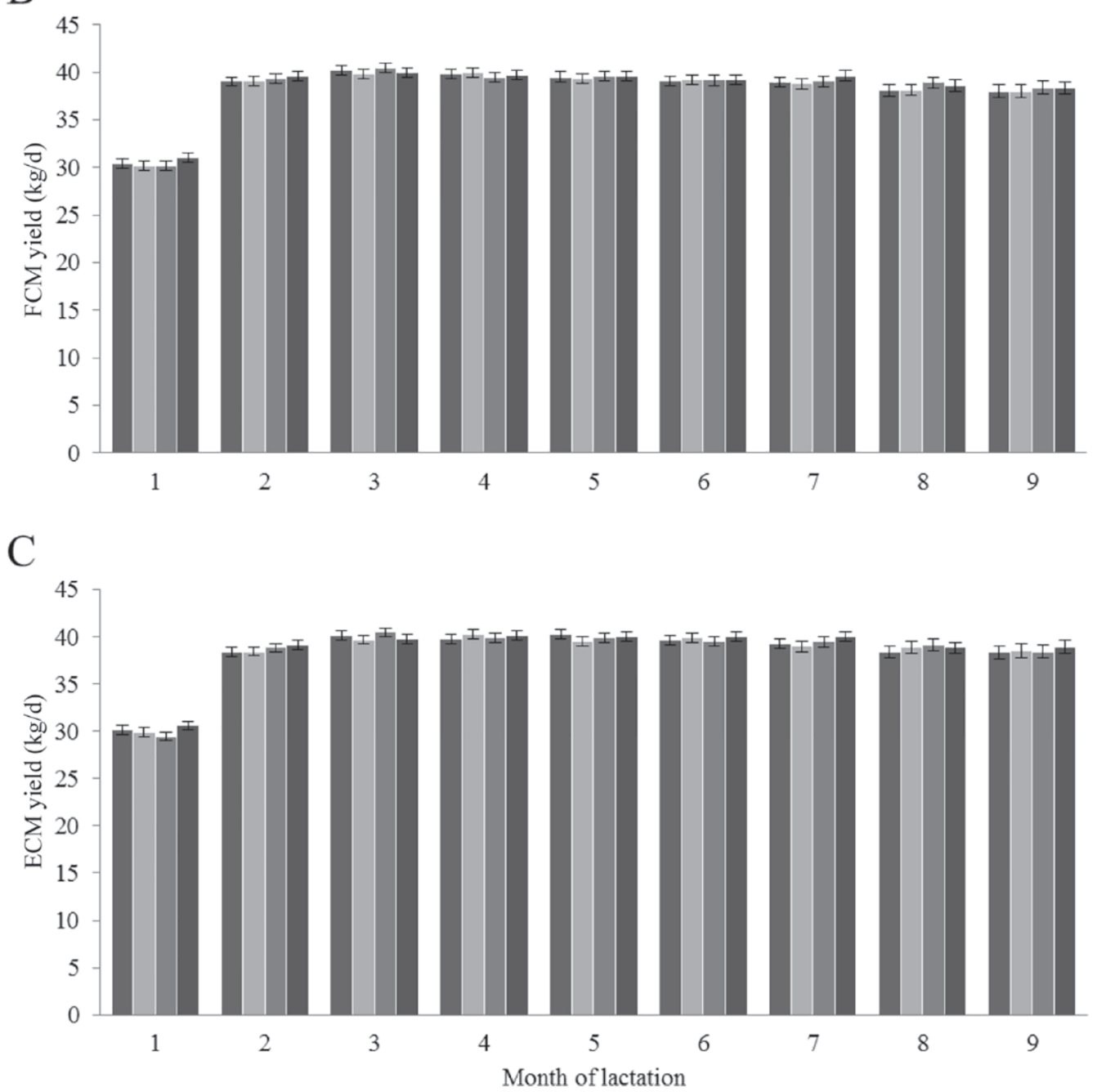

Figure 3. The effect of treatment on milk yield (A), 3.5\% FCM yield (B), and ECM yield (C). The average milk yield, 3.5\% FCM yield, and ECM yield for control cows (CON) and cows that received an internal teat sealant (ITS; $2.6 \mathrm{~g}$ of bismuth subnitrate), intramammary application of antibiotic (IA; $62.5 \mathrm{mg}$ of amoxicillin), or the combination of antibiotic and internal teat sealant (IA+ITS) are presented in Table 5. The error bars indicate SEM. 
Table 6. Cox's proportional hazard analyses evaluating the effect of treatment on the hazard of pregnancy and the hazard of culling or death

\begin{tabular}{lccc}
\hline Item $^{1}$ & Adjusted hazard ratio $(95 \% \mathrm{CI})$ & Individual $P$-value & Overall $P$-value \\
\hline Pregnancy & $1.07(0.85-1.34)$ & 0.55 & 0.63 \\
ITS vs. CON & $0.99(0.80-1.25)$ & 0.99 & \\
IA vs. CON & $1.13(0.91-1.41)$ & 0.27 & 0.26 \\
IA+ITS vs. CON & & 0.73 & \\
Culling or death & $1.08(0.70-1.66)$ & 0.25 & \\
ITS vs. CON & $0.76(0.48-1.21)$ & 0.20 & \\
IA vs. CON & $0.73(0.46-1.18)$ & & \\
IA+ITS vs. CON &
\end{tabular}

${ }^{1} \mathrm{CON}=$ control, no intervention; ITS $=$ internal teat sealant $(2.6 \mathrm{~g}$ of bismuth subnitrate $)$; IA = intramammary antibiotic (62.5 $\mathrm{mg}$ of amoxicillin); IA+ITS = intramammary antibiotic (62.5 $\mathrm{mg}$ of amoxicillin) followed by internal teat sealant ( $2.6 \mathrm{~g}$ of bismuth subnitrate).


Figure 4. Kaplan-Meier survival analyses of calving-to-conception interval $(\mathrm{A}, P=0.55)$, and probability of culling or death $(\mathrm{B}, P=$ $0.31)$ for control cows $(\mathrm{CON})$ and cows that received an internal teat sealant (ITS; $2.6 \mathrm{~g}$ of bismuth subnitrate), intramammary application of antibiotic (IA; $62.5 \mathrm{mg}$ of amoxicillin), or the combination of antibiotic and internal teat sealant (IA+ITS). vobiocin (Oliver et al., 2004), and pirlimycin (Oliver et al., 2004; Middleton et al., 2005). As discussed earlier, we cannot report the prepartum IMI prevalence nor cure rates as others did (Oliver et al., 1992; Middleton et al., 2005; Borm et al., 2006), but our results suggest that IA was efficacious to treat prepartum IMI. We found that IA reduced the postpartum intramammary presence of pathogens compared with untreated cows, which was also observed previously (Oliver et al., 2003, 2004). Additionally, we found that IA cows had decreased SCC linear scores throughout the study period, when compared untreated counterparts, which was also observed by another study (Oliver et al., 2003). It is important to highlight that this beneficial effect on SCC was not observed by others (Middleton et al., 2005; Borm et al., 2006). We speculated that the different antimicrobials used could be an explanation for the divergence in SCC results between studies. A review article suggested that these discrepancies are most likely due to herd-specific factors that are not yet identified (De Vliegher et al., 2012). Those authors observed that studies reporting improved clinical outcomes due to IA therapy had higher prevalence of IMI caused by major pathogens, whereas studies reporting a lack of treatment effect found higher prevalence of prepartum IMI caused by CNS. This observation is not in agreement with our results, as the most prevalent pathogen found in our samples was CNS; however, we still observed a decrease in SCC due to IA. The effect of this pathogen on udder health has been reported as being neutral (Schukken et al., 2009), beneficial (De Vliegher et al., 2003), and detrimental (Taponen et al., 2007). Additionally, early-lactation IMI caused by CNS was reported to be neutral (Kirk et al., 1996) or beneficial (Compton et al., 2007; Piepers et al., 2010) to milk production of dairy heifers. These findings suggest that herd or environmental factors could influence how CNS affects udder health in heifers. We acknowledge that only collecting samples from a subset of animals could have affected our observation. In total, we col- 
lected composite milk samples from 509 animals from $7 \pm 3$ DIM. Although sampling was conducted with great efforts and emphasis on presampling disinfection of teat ends and hygiene during sampling, $25 \%$ of samples were contaminated and were excluded from the final analysis; this proportion of contaminated samples is much higher than other have reported (Parker et al., 2007, 2008; Sampimon et al., 2009). A couple of factors could have contributed to this high proportion of contaminated samples; for example, the restless nature of primiparous cows and the lack of restraining during sampling. Samples were being collected at the first week of the heifers' lactation, when they are not used to having their teats manipulated. As heifers were moving during sampling, debris could have entered the sample collection tube, leading to contamination. Additionally, samples were collected after milking, instead of before milking. We acknowledge that this methodology is not what is recommended for milk sampling collections. We decided to collect samples after milking because the animals were being milked in a rotary parlor, and it would be unfeasible to collect samples before milking without disrupting the farms' routine.

To the best of our knowledge, this is the first study reporting the effect of prepartum IA followed by ITS. Similar to IA, IA+ITS also decreased the prevalence of IMI postpartum and the SCC linear score throughout the first 9 mo of lactation. In addition to this positive effect on SCC, IA+ITS also decreased the incidence of clinical and subclinical mastitis compared with CON, which was not observed for IA alone. This is in agreement with our hypothesis that the best results on udder health would be achieved with IA+ITS. However, we were expecting that ITS alone would improve udder health by reducing, to a lesser degree, clinical mastitis incidence and SCC. It is possible that even with all the efforts on teat disinfection before treatment application, bacteria from teat skin and teat canal was pushed into the mammary gland when ITS was applied, leading to the establishment of IMI. However, this speculation is not supported by our own bacteriological results. Pathogens were not detected in any of the 104 milk samples collected for ITS animals.

Although IA+ITS decreased the incidence of clinical mastitis within the first 9 mo of lactation, it did not decrease the incidence of clinical mastitis cases treated with intramammary antibiotics. On the farm where the study was conducted, mastitis cases that were negative for Streptococcus spp. were not treated with intramammary antibiotics. This approach follows the foundation of selective treatment of clinical mastitis, which antimicrobial treatments are only used on cases that would benefit from them. Pathogens are not cultured in about one third of clinical mastitis cases, hence not justifying the use of antimicrobials for those cases (Oliveira and Ruegg, 2014). Additionally, in clinical mastitis caused by gram-negative organisms, antimicrobial use is often not recommended because of the high rate of spontaneous cure and the limited activity of antimicrobials against those bacteria (Roberson et al., 2004; Ganda et al., 2016). Evidence shows that, when treated with intramammary antibiotics, cure rates of clinical mastitis caused by Staph. aureus can be as low as 35\% for chronic infections (Owens et al., 1997). Thus, it is often recommended to isolate or cull cows with Staph. aureus mastitis to control the herd prevalence of this bacteria. On the other hand, intramammary antimicrobial therapy successfully treated clinical mastitis caused by environmental Strep. uberis, with cure rate as high as $90 \%$ (Hillerton and Kliem, 2002); hence, the use of intramammary antibiotics to treat mastitis caused by this organism.

High SCC in early lactation has been associated with decreased milk production (De Vliegher et al., 2005b), impaired fertility (Bijker et al., 2015), and culling (De Vliegher et al., 2005a). Therefore, we hypothesized that the treatments that could decrease SCC in early lactation would also improve production, reproduction, and culling. Although IA and IA+ITS were efficacious in decreasing the SCC during early lactation, this did not reflect in better production, fertility, and culling outcomes. Sampimon et al. (2009) reported an increase in milk yield as a consequence of improved udder health due to IA therapy. However, the prevalence of major intramammary pathogens was higher than in their study, suggesting that the effect of such therapy on lactation performance can be linked to major pathogen prevalence.

In conclusion, ITS alone was not effective in improving udder health of heifers housed in freestall barns, whereas IA alone was effective in decreasing the SCC during the first 9 mo of lactation. The best results were achieved when IA was followed by ITS, improving udder health and milk quality by decreasing the incidence of clinical and subclinical mastitis and the SCC linear score throughout the lactation. However, growing concern exists regarding the potential effect of extensive use of antibiotics in food animals, as antibiotic resistance worldwide is recognized as a top public health challenge (Dolejska et al., 2011; Aust et al., 2012). Due to budget limitations, we did not evaluate how treatments influenced the susceptibility of intramammary bacterial isolates. Given that the beneficial results of prepartum IA therapy are inconsistent between herds (Borm et al., 2006), universal recommendations of this practice are not warranted. More research is needed to understand which herd factors could indicate the need of prepartum IA therapy. It was previously suggested 
that a herd may have a heifer mastitis problem if over $15 \%$ of heifers have clinical mastitis around parturition or if over $15 \%$ of heifers have SCC over 150,000 cells/mL in the first month of lactation (De Vliegher et al., 2012). Perhaps these parameters could be used to identify herds where prepartum IA therapy could benefit the heifers' udder health. It is important to highlight that intramammary infusion of antibiotics in precalving heifers may represent extra-label drug use, and this type of therapy should be done under the supervision of the herd veterinarian. Following Animal Medicinal Drug Use Clarification Act (AMDUCA) guidelines (AMDUCA, 1994), extended milk and meat withholding times should be prescribed. Additionally, AMDUCA limits extra-label drug use to situations when the health of an animal is in risk or when failure to treat can potentially be life-threatening. Thus, intramammary antibiotic therapy in prepartum heifers could be viewed as a contravention of AMDUCA if herds are not diagnosed as having a heifer mastitis problem or if heifers are treated without a IMI diagnosis. When Food Animal Residue Avoidance Databank (FARAD; http://www.farad.org/eldu/eldumain.asp) was consulted, they highlighted that extra label use of IA for prophylactic purposes is a gray area, but it could be allowed based on documentation of historical flock issues. Additionally, FARAD recommended a meat withdrawal interval of $13 \mathrm{~d}$ and a milk withdrawal interval of $72 \mathrm{~h}$. Milk residue testing should be performed on an individual level or before every milk shipment. Other management strategies should be pursued to improve heifer udder health, as prepartum IA therapy should not be continued for extended periods (De Vliegher et al., 2012).

\section{ACKNOWLEDGMENTS}

This project was funded by American Association of Bovine Practitioners (AABP, Ashland, OH) Foundation Competitive Research Grant 2016. The authors thank the owners and staff of the farm where the study was conducted.

\section{REFERENCES}

AMDUCA. 1994. Animal Medicinal Drug Use Clarification Act of 1994. Title 21, Code of Federal Regulations, Part 530 (21 CFR $530)$.

Aust, V., K. Knappstein, H. J. Kunz, H. Kaspar, J. Wallmann, and M. Kaske. 2012. Feeding untreated and pasteurized waste milk and bulk milk to calves: Effects on calf performance, health status and antibiotic resistance of faecal bacteria. J. Anim. Physiol. Anim. Nutr. (Berl.) 97:1091-1103. https://doi.org/10.1111/jpn.12019.

Barkema, H. W., Y. H. Schukken, T. J. Lam, M. L. Beiboer, H. Wilmink, G. Benedictus, and A. Brand. 1998. Incidence of clinical mastitis in dairy herds grouped in three categories by bulk milk somatic cell counts. J. Dairy Sci. 81:411-419. https://doi.org/10 .3168/jds.S0022-0302(98)75591-2.

Berry, E.A., and J.E. Hillerton. 2007. Effect of an intramammary teat seal and dry cow antibiotic in relation to dry period length on postpartum mastitis. J. Dairy Sci. 90:760-765.

Bijker, I., R. M. Christley, R. F. Smith, and H. Dobson. 2015. Effect of signs of oestrus, disease stressors and cow activity on pregnancy rate following artificial insemination. Vet. Rec. 176:411. https:// doi.org/10.1136/vr.102776.

Boland, F., L. O. Grady, and S. J. More. 2013. Investigating a dilution effect between somatic cell count and milk yield and estimating milk production losses in Irish dairy cattle. J. Dairy Sci. 96:14771484. https://doi.org/10.3168/jds.2012-6025.

Borm, A. A., L. K. Fox, K. E. Leslie, J. S. Hogan, S. M. Andrew, K. M. Moyes, S. P. Oliver, Y. H. Schukken, D. D. Hancock, C. T. Gaskins, W. E. Owens, and C. Norman. 2006. Effects of prepartum intramammary antibiotic therapy on udder health, milk production, and reproductive performance in dairy heifers. J. Dairy Sci. 89:2090-2098. https://doi.org/10.3168/jds.S0022-0302(06)72279 $-2$

Bramley, A. J., and F. H. Dodd. 1984. Reviews of the progress of dairy science: Mastitis control-Progress and prospects. J. Dairy Res. 51:481-512.

Bryan, M., and K. Taylor. 2009. Periparturient use of parenteral micronised procaine penicillin to reduce the risk of clinical mastitis in heifers after calving. Vet. Microbiol. 134:143-149. https://doi.org/ 10.1016/j.vetmic.2008.09.021.

Compton, C. W., F. R. Emslie, and S. McDougall. 2014. Randomised controlled trials demonstrate efficacy of a novel internal teat sealant to prevent new intramammary infections in dairy cows and heifers. N. Z. Vet. J. 62:258-266. https://doi.org/10.1080/ 00480169.2014.898201

Compton, C. W., C. Heuer, K. Parker, and S. McDougall. 2007a. Risk factors for peripartum mastitis in pasture-grazed dairy heifers. J. Dairy Sci. 90:4171-4180. S0022-0302(07)71876-3 [pii].

Compton, C. W.. C. Heuer, K. Parker, and S. McDougall. 2007b. Epidemiology of mastitis in pasture-grazed peripartum dairy heifers and its effects on productivity. J. Dairy Sci. 90:4157-4170.

De Vliegher, S., H. W. Barkema, G. Opsomer, A. de Kruif, and L. Duchateau. 2005a. Association Between somatic cell count in early lactation and culling of dairy heifers using cox frailty models. J. Dairy Sci. 88:560-568. https://doi.org/10.3168/jds.S0022 -0302(05)72718-1.

De Vliegher, S., H. W. Barkema, H. Stryhn, G. Opsomer, and A. de Kruif. 2004. Impact of early lactation somatic cell count in heifers on somatic cell counts over the first lactation. J. Dairy Sci. 87:3672-3682. https://doi.org/10.3168/jds.S0022-0302(04)73506 $-7$.

De Vliegher, S., H. W. Barkema, H. Stryhn, G. Opsomer, and A. de Kruif. 2005b. Impact of early lactation somatic cell count in heifers on milk yield over the first lactation. J. Dairy Sci. 88:938-947. https://doi.org/10.3168/jds.S0022-0302(05)72761-2.

De Vliegher, S., L. K. Fox, S. Piepers, S. McDougall, and H. W. Barkema. 2012. Invited review: Mastitis in dairy heifers: Nature of the disease, potential impact, prevention, and control. J. Dairy Sci. 95:1025-1040. https://doi.org/10.3168/jds.2010-4074.

De Vliegher, S., H. Laevens, L. A. Devriese, G. Opsomer, J. L. M. Leroy, H. W. Barkema, and A. de Kruif. 2003. Prepartum teat apex colonization with Staphylococcus chromogenes in dairy heifers is associated with low somatic cell count in early lactation. Vet. Microbiol. 92:245-252

Dolejska, M., Z. Jurcickova, I. Literak, L. Pokludova, J. Bures, A Hera, L. Kohoutova, J. Smola, and A. Cizek. 2011. IncN plasmids carrying bla CTX-M-1 in Escherichia coli isolates on a dairy farm. Vet. Microbiol. 149:513-516. https://doi.org/10.1016/j.vetmic 2010.11.032.

Edmonson, A. J., I. J. Lean, L. D. Weaver, T. Farver, and G. Webster 1989. A body condition scoring chart for Holstein dairy cows. J. Dairy Sci. 72:68-78.

Enger, B. D., L. K. Fox, J. M. Gay, and K. A. Johnson. 2015. Reduction of teat skin mastitis pathogen loads: Differences between 
strains, dips, and contact times. J. Dairy Sci. 98:1354-1361. https://doi.org/10.3168/jds.2014-8622.

Fox, L. K. 2009. Prevalence, incidence and risk factors of heifer mastitis. Vet. Microbiol. 134:82-88. https://doi.org/10.1016/j.vetmic 2008.09.005

Fricke, P. M., D. Z. Caraviello, K. A. Weigel, and M. L. Welle. 2003. Fertility of dairy cows after resynchronization of ovulation at three intervals following first timed insemination. J. Dairy Sci. 86:39413950. https://doi.org/10.3168/jds.S0022-0302(03)74003-X.

Ganda, E. K., R. S. Bisinotto, S. F. Lima, K. Kronauer, D. H. Decter, G. Oikonomou, Y. H. Schukken, and R. C. Bicalho. 2016. Longitudinal metagenomic profiling of bovine milk to assess the impact of intramammary treatment using a third-generation cephalosporin. Sci. Rep. 6:37565. https://doi.org/10.1038/srep37565.

Godden, S., P. Rapnicki, S. Stewart, J. Fetrow, A. Johnson, R. Bey, and R. Farnsworth. 2003. Effectiveness of an internal teat seal in the prevention of new intramammary infections during the dry and early-lactation periods in dairy cows when used with a dry cow intramammary antibiotic. J. Dairy Sci. 86:3899-3911. S00220302(03)73998-8 [pii].

Green, M. J., L. E. Green, G. F. Medley, Y. H. Schukken, and A. J. Bradley. 2002. Influence of dry period bacterial intramammary infection on clinical mastitis in dairy cows. J. Dairy Sci. 85:2589 2599. S0022-0302(02)74343-9 [pii].

Halasa, T., K. Huijps, O. Osteras, and H. Hogeveen. 2007. Economic effects of bovine mastitis and mastitis management: A review. Vet. Q. 29:18-31. https://doi.org/10.1080/01652176.2007.9695224.

Hand, K. J., A. Godkin, and D. F. Kelton. 2012. Milk production and somatic cell counts: A cow-level analysis. J. Dairy Sci. 95:13581362. https://doi.org/10.3168/jds.2011-4927.

Hillerton, J. E., and K. E. Kliem. 2002. Effective treatment of Streptococcus uberis clinical mastitis to minimize the use of antibiotics. J. Dairy Sci. 85:1009-1014. https://doi.org/10.3168/jds.S0022 -0302(02)74161-1.

Huxley, J. N., M. J. Greent, L. E. Green, and A. J. Bradley. 2002. Evaluation of the efficacy of an internal teat sealer during the dry period. J. Dairy Sci. 85:551-561.

Kirk, J. H., J. C. Wright, S. L. Berry, J. P. Reynolds, J. P. Maas, and A. Ahmadi. 1996. Relationships of milk culture status at calving with somatic cell counts and milk production of dairy heifers during early lactation on a Californian dairy. Prev. Vet. Med. 28:187198. https://doi.org/10.1016/0167-5877(96)01037-9.

Klei, L., J. Yun, A. Sapru, J. Lynch, D. Barbano, P. Sears, and D. Galton. 1998. Effects of milk somatic cell count on cottage cheese yield and quality. J. Dairy Sci. 81:1205-1213. https://doi.org/10 .3168/jds.S0022-0302(98)75680-2.

Kromker, V., and J. Friedrich. 2009. Teat canal closure in non-lactating heifers and its association with udder health in the consecutive lactation. Vet. Microbiol. 134:100-105. https://doi.org/10.1016/j vetmic.2008.09.002.

Laevens, H., H. Deluyker, Y. H. Schukken, L. De Meulemeester, R. Vandermeersch, E. De Muelenaere, and A. De Kruif. 1997. Influence of parity and stage of lactation on the somatic cell count in bacteriologically negative dairy cows. J. Dairy Sci. 80:3219-3226. https://doi.org/10.3168/jds.S0022-0302(97)76295-7.

Laven, R. A., and K. E. Lawrence. 2008. Efficacy of blanket treatment of cows and heifers with an internal teat sealant in reducing the risk of mastitis in dairy cattle calving on pasture. N. Z. Vet. J. 56:171-175. https://doi.org/10.1080/00480169.2008.36830.

Mazal, G., P. C. Vianna, M. V. Santos, and M. L. Gigante. 2007. Effect of somatic cell count on Prato cheese composition. J. Dairy Sci. 90:630-636. https://doi.org/10.3168/jds.S0022-0302(07)71545 -X.

McDougall, S., D. G. Arthur, M. A. Bryan, J. J. Vermunt, and A. M. Weir. 2007. Clinical and bacteriological response to treatment of clinical mastitis with one of three intramammary antibiotics. N. Z Vet. J. 55:161-170. https://doi.org/10.1080/00480169.2007.36762.

McDougall, S., K. I. Parker, C. Heuer, and C. W. Compton. 2009. A review of prevention and control of heifer mastitis via non-antibiotic strategies. Vet. Microbiol. 134:177-185. https://doi.org/10 .1016/j.vetmic.2008.09.026.
Middleton, J. R., L. L. Timms, G. R. Bader, J. Lakritz, C. D. Luby, and B. J. Steevens. 2005. Effect of prepartum intramammary treatment with pirlimycin hydrochloride on prevalence of early first-lactation mastitis in dairy heifers. J. Am. Vet. Med. Assoc. 227:1969-1974. https://doi.org/10.2460/javma.2005.227.1969.

Moreira, F., C. Orlandi, C. A. Risco, R. Mattos, F. Lopes, and W. W. Thatcher. 2001. Effects of presynchronization and bovine somatotropin on pregnancy rates to a timed artificial insemination protocol in lactating dairy cows. J. Dairy Sci. 84:1646-1659. https://doi .org/10.3168/jds.S0022-0302(01)74600-0.

NMC. 1999. Laboratory Handbook on Bovine Mastitis. rev. ed. National Mastitis Council, Madison, WI.

Norman, H. D., R. H. Miller, J. R. Wright, and G. R. Wiggans. 2000. Herd and state means for somatic cell count from dairy herd improvement. J. Dairy Sci. 83:2782-2788. https://doi.org/10.3168/ jds.S0022-0302(00)75175-7.

NRC. 2001. Nutrient Requirements of Dairy Cattle. 7th ed. Natl. Acad. Press, Washington, DC.

Oikonomou, G., V. S. Machado, C. Santisteban, Y. H. Schukken, and R. C. Bicalho. 2012. Microbial diversity of bovine mastitic milk as described by pyrosequencing of metagenomic $16 \mathrm{~s}$ rDNA. PLoS One 7:e47671. https://doi.org/10.1371/journal.pone.0047671.

Oliveira, L., and P. L. Ruegg. 2014. Treatments of clinical mastitis occurring in cows on 51 large dairy herds in Wisconsin. J. Dairy Sci. 97:5426-5436. https://doi.org/10.3168/jds.2013-7756.

Oliver, S. P., B. E. Gillespie, S. J. Ivey, M. J. Lewis, D. L. Johnson, K. C. Lamar, H. Moorehead, H. H. Dowlen, S. T. Chester, and J. W. Hallberg. 2004. Influence of prepartum pirlimycin hydrochloride or penicillin-novobiocin therapy on mastitis in heifers during early lactation. J. Dairy Sci. 87:1727-1731. https://doi.org/10.3168/jds .S0022-0302(04)73326-3.

Oliver, S.P., M.J. Lewis, B.E. Gillespie, and H.H. Dowlen. 1992. Influence of prepartum antibiotic therapy on intramammary infections in primigravid heifers during early lactation. J. Dairy Sci. 75:406-414.

Oliver, S. P., M. J. Lewis, B. E. Gillespie, and H. H. Dowlen. 1997. Antibiotic residues and prevalence of mastitis pathogen isolation in heifers during early lactation following prepartum antibiotic therapy. Zentralbl. Veterinarmed. B. 44:213-220.

Oliver, S.P., M.J. Lewis, B.E. Gillespie, H.H. Dowlen, E.C. Jaenicke, and R.K. Roberts. 2003. Prepartum antibiotic treatment of heifers: milk production, milk quality and economic benefit. J. Dairy Sci 86:1187-1193.

Owens, W. E., S. C. Nickerson, R. L. Boddie, G. M. Tomita, and C. H. Ray. 2001. Prevalence of mastitis in dairy heifers and effectiveness of antibiotic therapy. J. Dairy Sci. 84:814-817. https://doi.org/10 .3168/jds.S0022-0302(01)74538-9.

Owens, W. E., S. C. Nickerson, P. J. Washburn, and C. H. Ray. 1994 Prepartum antibiotic therapy with a cephapirin dry-cow product against naturally occurring intramammary infections in heifers. Zentralbl. Veterinarmed. B. 41:90-100.

Owens, W. E., C. H. Ray, J. L. Watts, and R. J. Yancey. 1997. Comparison of success of antibiotic therapy during lactation and results of antimicrobial susceptibility tests for bovine mastitis. J. Dairy Sci. 80:313-317. https://doi.org/10.3168/jds.S0022-0302(97)75940 -X.

Parker, K. I., C. Compton, F. M. Anniss, A. Weir, C. Heuer, and S. McDougall. 2007. Subclinical and clinical mastitis in heifers following the use of a teat sealant precalving. J. Dairy Sci. 90:207-218.

Parker, K.I., C.W. Compton, F.M. Anniss, C. Heuer, and S. McDougall. 2008. Quarter-level analysis of subclinical and clinical mastitis in primiparous heifers following the use of a teat sealant or an injectable antibiotic, or both, precalving. J. Dairy Sci. 91:169-181.

Passchyn, P., S. Piepers, and S. De Vliegher. 2013. Systemic prepartum treatment of end-term dairy heifers with penethamate hydriodide: Effect on udder health, milk yield, and culling until 120 days in milk. J. Dairy Sci. 96:6324-6335. https://doi.org/10.3168/ jds.2013-6626.

Piepers, S., G. Opsomer, H. W. Barkema, A. de Kruif, and S. De Vliegher. 2010. Heifers infected with coagulase-negative staphylococci in early lactation have fewer cases of clinical mastitis and 
higher milk production in their first lactation than noninfected heifers. J. Dairy Sci. 93:2014-2024. https://doi.org/10.3168/jds $.2009-2897$.

Pursley, J. R., M. O. Mee, and M. C. Wiltbank. 1995. Synchronization of ovulation in dairy cows using PGF2alpha and GnRH. Theriogenology 44:915-923.

Roberson, J. R., L. D. Warnick, and G. Moore. 2004. Mild to moderate clinical mastitis: Efficacy of intramammary amoxicillin, frequent milk-out, a combined intramammary amoxicillin, and frequent milk-out treatment versus no treatment. J. Dairy Sci. 87:583-592. https://doi.org/10.3168/jds.S0022-0302(04)73200-2.

Runciman, D. J., J. Malmo, and M. Deighton. 2010. The use of an internal teat sealant in combination with cloxacillin dry cow therapy for the prevention of clinical and subclinical mastitis in seasonal calving dairy cows. J. Dairy Sci. 93:4582-4591. https://doi.org/10 $.3168 /$ jds.2009-2956.

Sampimon, O. C., S. De Vliegher, H. W. Barkema, J. Sol, and T. J. G. M. Lam. 2009. Effect of prepartum dry cow antibiotic treatment in dairy heifers on udder health and milk production. J. Dairy Sci. 92:4395-4403. https://doi.org/10.3168/jds.2009-2203.

Schepers, A. J., T. J. Lam, Y. H. Schukken, J. B. Wilmink, and W. J. Hanekamp. 1997. Estimation of variance components for somatic cell counts to determine thresholds for uninfected quarters. J. Dairy Sci. 80:1833-1840. https://doi.org/10.3168/jds.S0022 -0302(97)76118-6.

Schukken, Y. H., R. N. González, L. L. Tikofsky, H. F. Schulte, C. G. Santisteban, F. L. Welcome, G. J. Bennett, M. J. Zurakowski, and R. N. Zadoks. 2009. CNS mastitis: Nothing to worry about? Vet. Microbiol. 134:9-14. https://doi.org/10.1016/j.vetmic.2008 .09 .014
Schukken, Y. H., D. J. Wilson, F. Welcome, L. Garrison-Tikofsky, and R. N. Gonzalez. 2003. Monitoring udder health and milk quality using somatic cell counts. Vet. Res. 34:579-596. http://dx.doi.org/ https://doi.org/10.1051/vetres:2003028.

Taponen, S., J. Koort, J. Björkroth, H. Saloniemi, and S. Pyörälä. 2007. Bovine intramammary infections caused by coagulase-negative staphylococci may persist throughout lactation according to amplified fragment length polymorphism-based analysis. J. Dairy Sci. 90:3301-3307. https://doi.org/10.3168/jds.2006-860.

Trinidad, P., S. C. Nickerson, T. K. Alley, and R. W. Adkinson. 1990. Efficacy of intramammary treatment in unbred and primigravid dairy heifers. J. Am. Vet. Med. Assoc. 197:465-470.

Tyler, J. W., M. C. Thurmond, and L. Lasslo. 1989. Relationship between test-day measures of somatic cell count and milk production in California dairy cows. Can. J. Vet. Res. 53:182-187.

USDA-NAHMS (National Animal Health Monitoring System). 2014 Dairy 2014: Milk Quality, Milking Procedures, and Mastitis on U.S. Dairies, 2014. Accessed Aug. 30, 2017. https://www.aphis .usda.gov/animal_health/nahms/dairy/downloads/dairy14/ Dairy14_dr_Mastitis.pdf.

Waage, S., S. Sviland, and S. A. Ødegaard. 1998. Identification of risk factors for clinical mastitis in dairy heifers. J. Dairy Sci. 81:12751284. https://doi.org/10.3168/jds.S0022-0302(98)75689-9.

Woolford, M. W., J. H. Williamson, A. M. Day, and P. J. Copeman. 1998. The prophylactic effect of a teat sealer on bovine mastitis during the dry period and the following lactation. N. Z. Vet. J. 46:12-19. https://doi.org/10.1080/00480169.1998.36044. 